\title{
ANALISIS FAKTOR RISIKO PEMBERIAN ASI DAN VENTILASI KAMAR TERHADAP KEJADIAN PNEUMONIA BALITA
}

\author{
Bagus Ali Fikri \\ Departemen Epidemiologi \\ Fakultas Kesehatan Masyarakat, Universitas Airlangga \\ Campus C Airlangga University Mulyorejo-60115 \\ Alamat Korespondensi: \\ Email: bagus.ali.fikri@gmail.com
}

\begin{abstract}
Pneumonia is still a major cause of infant mortality in the world amounted to $18 \%$ of infant mortality caused by pneumonia, nor in Indonesia amounted to $13 \%$ of infant mortality contributed by pneumonia and pneumonia incidence was highest in children aged 1-4 years. Some of the possible interventions to reduce the incidence of pneumonia is exclusive breastfeeding, immunization that associated with pneumonia, and reduce air pollution in the house. This type of research is an analytic observational with case control design. Case population is all toddlers diagnosed with pneumonia in the August to December 2015 period, while the control population is all children who are diagnosed does not pneumonia in the period. The method used for this research is total sampling which resulted of 40 toddlers. The independent variables used were a history of exclusive breastfeeding and the room ventilation. The results of this study are exclusive breastfeeding $(O R=7.407)$ and the room ventilation $(O R=13.5)$ at risk for pneumonia. Based on these results the government must improve the dissemination of exclusive breastfeeding, one of them with advertising. Parents of toddlers must improve air circulation in the room by improving size of ventilation or manipulate the air condition of toddler room to better circulation, of one of them by giving the fan and blower installation in toddler rooms.
\end{abstract}

Keywords: exclusive breastfeeding, risk factor, room ventilation, toddler pneumonia.

\begin{abstract}
ABSTRAK
Pneumonia masih merupakan penyebab kematian utama balita di dunia sebesar 18\% kematian balita diakibatkan oleh pneumonia, begitupula di Indonesia sebesar 13\% kematian balita disumbang oleh pneumonia dan kejadian pneumonia tertinggi terjadi pada anak berusia 1-4 tahun. Beberapa intervensi yang dapat dilakukan guna mengurangi kejadian pneumonia adalah pemberian ASI eksklusif, imuniasi yang berhubungan dengan pneumonia, dan mengurangi polusi udara dalam rumah. Penelitian ini merupakan penelitian observasional analitik yang menggunakan rancangan case control. Semua balita yang didiagnosis menderita pneumonia periode Agustus sampai Desember 2015 di Rumah Sakit Umum Daerah Sidoarjo (RSUD Sidoarjo) menjadi populasi kasus dan populasi kontrol adalah semua balita yang didiagnosis tidak menderita pneumonia pada periode tersebut. Metode penelitian ini menggunakan total sampling 40 responden balita. Variabel bebas yang digunakan adalah riwayat pemberian ASI eksklusif dan luas ventilasi ruangan. Hasil penelitian ini adalah pemberian ASI eksklusif $(\mathrm{OR}=7,407)$ dan luas ventilasi ruangan $(\mathrm{OR}=13,5)$ berisiko terhadap kejadian pneumonia. Berdasarkan hasil tersebut diharapkan pemerintah meningkatkan sosialisasi ASI eksklusif salah satunya dengan iklan. Bagi orang tua balita diharapkan agar memperbaiki sirkulasi udara dalam ruangan dengan cara memperbaiki ventilasi yang luasnya masih kurang ataupun memanipulasi kondisi udara ruangan kamar balita agar lebih baik sirkulasinya salah satunya dengan pemberian kipas dan pemasangan blower pada ruangan kamar.
\end{abstract}

Kata Kunci: ASI eksklusif, faktor risiko, ventilasi ruangan, pneumonia balita 


\section{PENDAHULUAN}

Pneumonia masih menjadi masalah pada usia balita. Pneumonia masih menjadi pembunuh balita nomer satu, dimana sebesar $18 \%$ dari total penyebab kematian balita disebabkan oleh pneumonia. Penyebab kematian terbesar berikutnya setelah pneumonia adalah diare sebesar $10 \%$. Keduanya menyebabkan kematian sebesar 2 juta balita setiap tahunnya. Kematian oleh pneumonia pada balita sebesar 4\% disumbang ketika bayi baru dilahirkan, dapat dikatakan jika diagnosa dan penatalaksanaan pneumonia berpengaruh besar dalam mempengaruhi angka kematian balita akibat pneumonia di dunia (WHO, 2013).

Di Indonesia pneumonia juga masih menjadi masalah kesehatan pada balita. Jumlah kasus pneumonia balita di Indonesia pada tahun 2012 adalah sebesar 549.708 kasus sedangkan pada tahun 2013 sebesar 571.547 kasus. Terjadi peningkatan kasus yang cukup signifikan yaitu sebesar 25\% dari kasus pneumonia sebelumnya. Angka kematian balita akibat pneumonia juga menunjukkan kenaikan yang sangat signifikan dimana angka kematian balita akibat pneumonia pada tahun 2012 sebesar 609 balita sedangkan pada tahun 2013 sebesar 6774 balita. Kenaikan angka kematian balita akibat pneumonia mencapai lebih dari $600 \%$ dari tahun sebelumnya, hal ini hendaknya menjadi perhatian serius pemerintah untuk menangani kasus pneumonia dari penemuan, intervensi, diagnosa dan pengobatan pneumonia khususnya bagi balita. (Kemenkes RI., 2013 dan 2014).

Temuan kasus yang masih rendah, kurang spesifiknya gejala-gejala yang ditimbulkan, sedikitnya penanganan dengan antibiotik dan kurangnya data yang tersedia, menyebabkan pneumonia mendapatkan julukan the forgotten killer of children atau the forgotten disease. Sebutan pneumonia menjadi pembunuh anak-anak yang terlupakan, tidak terlepas dari data yang ada. Salah satu negara berkembang seperti Indonesia jika dibandingkan dengan negara tetangga seperti Thailand, terapi antibiotik yang dilakukan untuk menangani pneumonia oleh Thailand (65\%) lebih tinggi 26\% dari Indonesia (39\%). Di Indonesia, penggunaan antibiotik untuk menangani pneumonia masih rendah dibandingkan dengan Thailand. Penemuan pneumonia di Indonesia yang dibawa ke fasilitas pelayanan kesehatan terpaut $10 \%$ dari Thailand dengan persentase penemuan sebesar $85 \%$, sedangkan Indonesia sebesar 75\% (Fikri, 2016).

Hasil Riskesdas 2007 menunjukan jika kematian balita akibat pneumonia sebesar $13 \%$ dari seluruh penyebab kematian balita. Kelompok yang lebih rentan adalah dengan umur lebih muda yaitu dibawah 1 tahun jika dibandingkan dengan umur diatasnya yaitu 1-4 tahun. Prevalensi pneumonia tertinggi terjadi pada kelompok umur 1-4 tahun, kemudian 45-54 tahun dan terus meningkat pada umur berikutnya. Pneumonia pada balita di Provinsi Jawa Timur pada tahun 2007 sebesar 1,55\% dan pada tahun 2013 sebesar $1,80 \%$, sehingga dapat diartikan bahwa terjadi kenaikan kejadian pneumonia di Provinsi Jawa Timur (Kemenkes RI., 2013).

Temuan kejadian pneumonia balita di Jawa Timur belum mencapat target yaitu hanya sebesar $27,08 \%$. Target cakupan penemuan penderita pneumonia balita harusnya adalah $80 \%$ untuk meningkatkan penanganan balita yang menderita pneumonia (Dinkes Prov. Jatim., 2013).

Jumlah kasus pneumonia di Jawa Timur pada tahun 2012 sebesar 61.449 kasus dibandingkan dengan tahun 2013 sebesar 79.363, terjadi kenaikan yang cukup signifikan sebesar 3,4\% dari tahun sebelumnya. Kenaikan dengan angka kematian balita mengalami penurunan diantara kedua tahun tersebut, yaitu masingmasing 54 balita dan 8 balita. Penurunan angka kematian balita akibat pneumonia menunjukkan diagnosis dan penanganan pneumonia yang meningkat di provinsi Jawa Timur (Kemenkes RI., 2013 dan 2014). 
Pneumonia adalah penyakit infeksi yang sangat erat dengan kondisi lingkungan. Penularan pneumonia menggunakan udara sebagai media penularannya sehingga sering dikaitkan dengan kondisi hunian rumah penderita. Hunian yang sehat atau rumah sehat harus memberikan kenyamanan, keamanan, keselamatan, dan kesehatan. Kebutuhan kesehatan minimal harus memenuhi tiga aspek yaitu tersedianya pencahayaan yang cukup, peghawaan yang baik, suhu udara normal dan kelembapan normal. Kriteria penghawaan merupakan kriteria yang berhubungan dengan kualitas udara dalam ruang dimana udara yang bersih akan meningkatkan kualitas hidup individu yang hidup didalamnya, sedangkan kualitas udara yang buruk maka akan memudahkan individu didalamnya mudah untuk terserang penyakit khususnya penyakit yang mudah menular lewat udara seperti pneumonia (Mahalastri, 2014).

Pneumonia adalah adanya inflamasi, pembengkakan atau peradangan pada jaringan parenkim paru yang biasanya dikaitkan dengan pengisian alveoli dengan cairan. Pneumonia dapat diklasifikasikan menurut agen penyebab ataupun area paru yang terkena pneumonia. Berdasarkan agen penyebab, pneumonia dibagi menjadi tempat yaitu pneumonia tipikal (klasik) atau Community Acquired Pneumonia $(C A P)$, pneumonia atipikal (nosokomial), pneumonia aspirasi, dan pneumonia immunocompromised. Berdasarkan area paru yang terkena dibagi menjadi dua yaitu pneumonia lobaris dan bronchopneumonia (Wahid dan Imam, 2013).

Penyebab pneumonia pada balita paling sering adalah bakteri Streptococcus pneumoniae dan Haemophilus influenzae type $b$, keduanya merupakan flora normal dalam tubuh dan menyerang pada saat imunitas sedang rendah (WHO, 2013). Selain itu, pneumonia dapat disebabkan oleh mikroorganisme lain dari golongan bakteri seperti staphylococcus aureus, dari golongan virus seperti influenza, para influenza, adenovirus, virus sisisial pernapasan, hantaravirus, rhinovirus, wirus herpes simpleks, cytomegalovirus, mycoplasma, pneumococcus, streptococcus, dari golongan jamur seperti candidiasis, histoplasmosis, dan aspergifosis. Menurut aspek aspirasi dan inhalasi, pneumonia dapat ditimbulkan oleh makanan, cairan, racun, bahan kimia, rokok, debu ataupun gas. Balita lebih sering terkena virus sinsisial pernapasan (Respiratory Syncytial Virus), adenovirus, virus influenza dan mycoplasma (Wahid dan Imam, 2013).

Menurut Wahid dan Imam (2013), terdapat faktor yang meningkatkan risiko terkena pneumonia dan adapula faktor yang meningkatkan risiko kematian akibat pneumonia. Faktor yang meningkatkan risiko terkena pneumonia diantaranya adalah infeksi saluran pernapasan atas, umur dibawah 2 bulan, usia lanjut, malnutrisi, berat bayi lahir rendah, imunisasi tidak lengkap, tidak mendapatkan ASI eksklusif dan polusi udara. Faktor yang meningkatkan kematian akibat pneumonia adalah umur dibawah 2 bulan, sosio ekonomi yang rendah, gizi kurang, berat bayi lahir rendah, tingkat pendidikan yang rendah, pelayanan kesehatan rendah, kepadatan tempat tinggal, penyakit kronis dan imunisasi yang tidak lengkap.

Intervensi yang dilakukan untuk menurunkan angka kesakitan dan kematian balita pada kejadian ini adalah pemberian ASI secara eksklusif, imunisasi yang utamanya berhubungan dengan vaksin Streptococcus pneumoniae dan Haemophilus influenzae type $b$, serta vaksin campak dan pertusis, peningkatan kualitas sanitasi dan higiene tempat tinggal balita maupun mengurangi polusi udara dalam rumah (WHO, 2013).

Menurut data World Health Organization upaya pemberian ASI eksklusif masih menjadi upaya terendah kedua setelah pemberian antibiotik untuk kejadian pneumonia dibandingkan dengan upaya yang lain. Pemberian antibiotik di negara berkembanglah yang menyumbang angka paling sedikit untuk penanganan pneumonia menggunakan antibiotik jika 
dibandingan dengan negara maju, sedangkan program peningkatan sanitasi lingkungan juga berkaitan dengan sistem ekonomi suatu Negara dimana negara berkembang pasti memiliki fasilitas dan kualitas ekonomi yang kurang baik dan berimplikasi pada sistem kesehatan di suatu negara (WHO, 2013).

Rumah sakit adalah salah satu tempat pelayanan kesehatan yang terlengkap dari segi fasilitas, penemuan kasus, diagnosa, penanganan dan pengobatan penyakit. Di rumah sakit, diagnosa pneumonia dapat dilakukan dengan lebih tepat dan beragam dari mulai pemeriksaan fisik, uji laboratorium sampai dengan pemeriksaan radiologi seperti chest $x$-ray. Diagnosa inilah yang mendasari penemuan kasus yang sesuai dan penanganan yang tepat. Menurut Hartati dkk. (2012) penemuan kasus pneumonia termasuk dalam kategori 10 penyakit penyebab kematian tertinggi. Di RSUD Pasar Rebo kasus pneumonia balita pada bulan April sampai dengan Mei 2011 mencapai 242 balita sedangkan di RSUD Sidoarjo jumlah kasus pneumonia balita pada tahun 2015 mencapai 96 balita (Fikri, 2016).

Melihat data tersebut peneliti memfokuskan penelitian pada faktor risiko pneumonia, dimana langkah intervensi untuk mencegah terjadinya penyakit ini dapat ditingkatkan. Faktor risiko yang dipilih dalam penelitian ini adalah pemberian ASI secara eksklusif pada balita dan status ventilasi ruangan kamar balita.

ASI eksklusif adalah pemberian ASI pada bayi berusia 0-6 bulan tanpa adanya tambahan makanan ataupun cairan dalam bentuk apapun. Kandungan ASI cukup untuk bayi tanpa adanya tambahan makanan apapun (Sartono dan Hanik, 2012). ASI merupakan makanan terbaik bagi bayi diawal-awal masa pertumbuhannya, zat gizi yang diperlukan cukup untuk pertumbuhan fisik yang maksimal, disamping untuk pertumbuhan ASI dapat meningkatkan daya tahan tubuh dari infeksi yang menyerang. ASI melengkapi pertahanan tubuh balita sesaat setelah dilahirkan dengan membantu imunitas bawaan setelah lahir, salah satunya dengan bantuan immunoglobulin dalam kolostrum. Banyak penelitian yang membuktikan bahwa ASI dapat mengurangi risiko anak terkena berbagai macam penyakit (Sarbini dan Listyani, 2008).

Hasil penelitian oleh Puspitasari dan Fariani (2015) menyebutkan balita yang tidak diberi ASI eksklusif akan berisiko 7 kali terkena pneumonia daripada yang diberi ASI eksklusif. Pemberian ASI eksklusif cenderung kurang maksimal diakibatkan oleh kesadaran orang tua akan pentingnya ASI masih sangat kurang, padahal fungsi ASI sudah sangat jelas memiliki beragam manfaat bagi balita.

Faktor berikutnya yang berisiko terhadap kejadian pneumonia adalah luas ventilasi ruangan, menurut hasil penelitian Sugihartono dkk. (2012), balita yang luas ventilasi ruangannya kurang dari standar berisiko 6,4 kali lebih besar terkena pneumonia daripada yang luas ventilasinya baik. Luas ventilasi ruangan adalah salah satu indikator dari kebersihan udara dalam ruangan karena ventilasi udara berhubungan dengan sirkulasi udara dimana manusia sering beraktifitas didalam ruangan. Sirkulasi yang buruk akan mengakibatkan bakteri mudah berkembang dalam ruangan sehingga dapat menyebabkan pneumonia (Fikri, 2016).

Penelitian ini secara umum bertujuan untuk mengidentifikasi karakteristik responden meliputi umur dan jenis kelamin serta menganalisis faktor risiko riwayat pemberian ASI eksklusif dan status luas ventilasi ruangan kamar balita terhadap kejadian pneumonia balita.

\section{METODE PENELITIAN}

Rancang bangun penelitian ini adalah case control yang bertujuan untuk melihat besar risiko penyakit pneumonia dengan membandingkan kelompok kontrol dan kasus. Perjalanan penyakit dimulai dari status penyakit kembali ke status paparannya 
sehingga kemudian disebut pula peninjauan secara retrospektif.

Populasi sasaran yang digunakan adalah semua balita yang pernah dirawat di rawat inap RSUD Sidoarjo. Populasi kasus dalam penelitian ini adalah semua balita yang pernah berkunjung dan didiagnosis menderita pneumonia di rawat inap RSUD Sidoarjo pada periode Agustus sampai Desember 2015, sedangkan untuk populasi kontrolnya adalah semua balita yang pernah berkunjung dan didiagnosis menderita penyakit selain pneumonia di rawat inap RSUD Sidoarjo pada periode Agustus sampai Desember 2015. Sampel kasusnya adalah balita yang menderita pneumonia di rawat inap RSUD Sidoarjo periode Agustus sampai Desember 2015 dan sampel kontrolnya adalah balita yang menderita selain pneumonia di rawat inap RSUD Sidoarjo.

Kriteria inklusi pada kelompok sampel kasus meliputi balita yang menderita pneumonia tanpa disertai penyakit penyerta yang lain, balita berumur kurang dari sama dengan 5 tahun, balita yang memiliki ibu ataupun pengasuh, balita yang tinggal serumah dengan orang tua atau wali.

Pengambilan sampel menggunakan metode total sampling dengan jumlah sampel kasus yang memenuhi kriteria inklusi sebanyak 20 balita dan menggunakan perbandingan 1:1 untuk sampel kontrolnya sehingga didapatkan sampel kontrol sebanyak 20. Total sampel dari penelitian ini adalah 40 balita. Penelitian ini dilaksanakan dari bulan September 2015 sampai bulan Maret 2016.

Variabel independen (bebas) yaitu riwayat pemberian ASI eksklusif dengan definisi pemberian ASI tanpa adanya tambahan makanan atau minuman apapun selama 6 bulan dan luas ventilasi ruangan kamar balita dengan standar minimal $20 \%$ dari seluruh luas ruangan. Variabel dependen (terikat) pada penelitian ini adalah penumonia balita.

Penelitian ini menggunakan data perimer dan data sekunder. Data primer dikumpulkan menggunakan kuesioner pada responden yaitu ibu berbalita yang tinggal di Kabupaten Sidoarjo. Data sekunder berasal dari rekam medik pasien. Observasi juga dilakukan dengan mengukur luas ventilasi ruang kamar balita. Pengukuran luas ventilasi ruangan meliputi lubang jendela, lubang pintu dan lubang ventilasi lain yang ada di ruangan tersebut. Meteran gulung sebagai media untuk mengukur luas dari ventilasi di ruangan tersebut.

Analisis statistik digunakan untuk mengetahui frekuensi (analisis deskriptif karakteristik responden) variabel independen yang tersebar dalam sampel penelitian dan menghitung odds ratio (pengukuran analitik) menggunakan perintah risk estimate untuk menilai seberapa besar risiko yang dihasilkan antara variabel independen terhadap variabel dependen. Penelitian ini juga melihat kekuatan hubungan antar variabel penelitian dengan menambahkan perintah phi cramer's $v$.

\section{HASIL}

\section{Karakteristik Balita Menurut Umur dan Jenis Kelamin}

Umur balita dalam sampel penelitian dibagi menjadi dua kategori yaitu yang berumur $0-2$ tahun dan yang berumur 2-5 tahun. Balita yang berumur 0-2 tahun lebih banyak daripada yang berumur 2-5 tahun. Balita yang berumur 0-2 tahun berjumlah 29 balita dimana jumlah tersebut adalah 75,5 persen dari total sampel penelitian, kasus maupun kontrolnya.

Jenis kelamin balita dalam sampel penelitian dibagi menjadi dua kategori yaitu yang berjenis kelamin laki-laki dan yang berjenis kelamin perempuan.

Tabel 1. Distribusi Responden Menurut Umur

\begin{tabular}{lcc}
\hline \multirow{2}{*}{ Umur Balita } & \multicolumn{2}{c}{ Jumlah } \\
\cline { 2 - 3 } & $\mathbf{n}$ & $\mathbf{\%}$ \\
\hline 0-2 Tahun & 29 & $75,5 \%$ \\
2-5 Tahun & 11 & $27,5 \%$ \\
\hline Jumlah & 40 & $100 \%$ \\
\hline
\end{tabular}


Tabel 2. Distribusi Responden Menurut Jenis Kelamin

\begin{tabular}{|c|c|c|}
\hline \multirow{2}{*}{ Jenis Kelamin } & \multicolumn{2}{|c|}{ Jumlah } \\
\hline & $\mathbf{n}$ & $\%$ \\
\hline Laki-laki & 23 & $57,5 \%$ \\
\hline Perempuan & 17 & $42,5 \%$ \\
\hline Jumlah & 40 & $100 \%$ \\
\hline
\end{tabular}

Balita yang berjenis kelamin laki-laki lebih banyak daripada yang berjenis kelamin perempuan. Balita yang berjenis kelamin laki-laki berjumlah 23 balita dimana jumlah tersebut adalah 57,5 persen dari total sampel penelitian, sedangkan $42,5 \%$ sisanya adalah balita perempuan dalam sampel penelitian.

\section{Faktor Risiko Pneumonia pada Balita ASI Eksklusif}

Pada penelitian ini didapatkan presentase balita dalam sampel penelitian yang mendapatkan ASI eksklusif dari total 40 balita yang lebih banyak mendapatkan ASI eksklusif yaitu sebesar 23 balita (57,5\%), sedangkan sisanya sebesar 17 balita (42,5\%) tidak mendapatkan ASI eksklusif.

Dapat disimpulkan jika pemberian ASI eksklusif pada balita yang menderita pneumonia lebih sedikit, hanya sebesar 35\% saja.

Tabel 4 menunjukkan dalam sampel kasus, balita yang tidak mendapatkan ASI eksklusif lebih banyak daripada balita yang mendapatkan ASI eksklusif. Berbeda dengan sampel kontrol yang $80 \%$ balitanya telah mendapatkan ASI eksklusif.

Hasil analisis penelitian ini juga menunjukkan bahwa balita yang tidak

Tabel 3. Distribusi Responden Menurut Riwayat Asi Eksklusif

\begin{tabular}{lcc}
\hline \multirow{2}{*}{$\begin{array}{c}\text { Riwayat Pemberian Asi } \\
\text { Eksklusif }\end{array}$} & \multicolumn{2}{c}{ Jumlah } \\
\cline { 2 - 3 } & $\mathbf{n}$ & $\mathbf{\%}$ \\
\hline Tidak ASI Eksklusif & 17 & $42,5 \%$ \\
\hline ASI Eksklusif & 23 & $57,5 \%$ \\
\hline Jumlah & 40 & $100 \%$ \\
\hline
\end{tabular}

Tabel 4. Distribusi Responden Berdasarkan Pneumonia Balita Menurut Pemberian Asi Eksklusif pada Balita

\begin{tabular}{lcccc}
\hline \multirow{2}{*}{$\begin{array}{c}\text { Riwayat } \\
\text { Pemberian ASI } \\
\text { Eksklusif }\end{array}$} & n & $\%$ & n & $\%$ \\
\cline { 2 - 5 } & 13 & $65 \%$ & 4 & $20 \%$ \\
\hline Tidak & 7 & $35 \%$ & 16 & $80 \%$ \\
Ya & 20 & $100 \%$ & 20 & $100 \%$ \\
\hline Total & Phi cramer's $v=0,455$ \\
\hline OR $=7,407$ & \multicolumn{4}{c}{ Kontrol } \\
\hline
\end{tabular}

mendapatkan ASI eksklusif berisiko 7,407 kali lebih besar terkena pneumonia dari pada balita yang mendapatkan ASI eksklusif, meskipun kekuatan hubungannya cukup lemah karena hampir mendekati 0,5 yaitu 0,455 .

\section{Luas Ventilasi Ruangan}

Temuan dilapangan menunjukan jika jumlah balita dalam sampel penelitian lebih banyak yang sesuai dengan standar peraturan tersebut yaitu sebanyak $65 \%$ dari keseluruhan sampel penelitian, sedangkan sisanya sebesar $35 \%$ luas ventilasi ruangan balita tidak standar atau kurang dari 20\% luas lantai sebagaimana tertera pada tabel 5.

Tabel 6 menunjukkan dalam sampel kasus, balita yang luas ventilasi ruangan kamarnya kurang lebih banyak daripada balita yang luas kamarnya sudah sesuai standar. Sampel kontrol memiliki perbedaan yang signifikan antara luas ventilasi ruangannya yaitu sebanyak $90 \%$ balita yang luas ventilasinya sudah sesuai dengan standar, sehingga dapat diartikan balita

Tabel 5. Distribusi Responden Menurut Luas Ventilasi Ruangan

\begin{tabular}{|c|c|c|}
\hline \multirow{2}{*}{ Luas Ventilasi Ruangan } & \multicolumn{2}{|c|}{ Jumlah } \\
\hline & $\mathbf{n}$ & $\%$ \\
\hline$<20 \%$ Luas Lantai & 14 & $35 \%$ \\
\hline$\geq 20 \%$ Luas Lantai & 26 & $65 \%$ \\
\hline Jumlah & 40 & $100 \%$ \\
\hline
\end{tabular}


Tabel 6. Distribusi Responden Berdasarkan Pneumonia Balita Menurut Luas Ventilasi Ruangan Kamar Balita

\begin{tabular}{lllll}
\hline \multirow{2}{*}{$\begin{array}{c}\text { Luas Ventilasi } \\
\text { Ruangan }\end{array}$} & \multicolumn{2}{c}{ Kasus } & \multicolumn{2}{c}{ Kontrol } \\
\cline { 2 - 5 } & $\mathbf{n}$ & $\mathbf{\%}$ & \multicolumn{1}{c}{$\mathbf{n}$} & $\mathbf{\%}$ \\
\hline Kurang $(<20 \%)$ & 12 & $60 \%$ & 2 & $10 \%$ \\
Standar $(\geq 20 \%)$ & 8 & $40 \%$ & 18 & $90 \%$ \\
\hline Total & 20 & $100 \%$ & 20 & $100 \%$ \\
\hline OR $=13,5$ & Phi cramer’s v $=0,524$ \\
\hline
\end{tabular}

yang luas ventilasi ruangannya $\geq 20 \%$ lebih banyak yang tidak menderita pneumonia dibandingkan balita yang luas ventilasinya kurang dari standar.

Hasil analisis penelitian ini juga menunjukkan bahwa balita yang luas ventilasi ruangan kamarnya $<20 \%$ luas lantai berisiko 13,5 kali lebih besar terkena pneumonia daripada balita yang luas ventilasi ruangan kamarnya $\geq 20 \%$ luas lantai ruangannya, sedangkan untuk kuat hubungan antara luas ventilasi ruangan kamar balita dengan kejadian pneumonia dikategorikan cukup kuat karena melewati 0,5 yaitu 0,524 .

Hasil kedua variabel tersebut diatas, menunjukkan yang berisiko terbesar untuk timbulnya pneumonia balita adalah ruangan dengan luas ventilasi kurang dari 20\% luas lantai ruangan balita.

\section{PEMBAHASAN}

\section{Umur}

Pneumonia dapat menyerang siapapun dan golongan umur berapapun. Umur yang dimaksud disini adalah umur balita yaitu bayi dengan umur dibawah 5 tahun. Balita merupakan salah satu populasi rentan selain umur lanjut usia. Jumlah balita yang menderita pneumonia banyak yang berumur 0-2 tahun daripada yang berumur 2-5 tahun. Hal ini diperkuat dengan penelitian Hartati dkk. (2012) menyatakan jika imunitas balita saat berumur lebih muda atau baru dilahirkan lebih rendah dibandingkan umur diatasnya. Pernyataan tersebut sesuai dengan hasil penelitian bahwa jumlah umur balita yang lebih muda lebih banyak daripada yang berusia diatasnya. Penelitiannya juga menyatakan bayi dengan usia lebih muda (0-12 bulan) berisiko 3,24 kali menderita pneumonia daripada yang berusia diatas 1 tahun, menurutnya imunitas balita yang berusia dibawah 1 tahun memiliki imunitas yang masih sangat rendah dan rentan terkena penyakit, maka dari itu peran dari nutrisi khususnya ASI pada awal-awal kelahiran yang mengandung kolostrum lebih tinggi membantu balita untuk meningkatkan imunitasnya dengan kandungan immmunoglobulin A ( $\operatorname{Ig} A$ ) yang ada di dalamnya.

Balita dengan umur diatas 2 tahun tidak terlepas dari pneumonia karena masih tergolong rentan dari serangan penyakit. Balita diatas umur 2 tahun sudah tidak mendapatkan ASI melainkan pemenuhan kebutuhan gizi yang utama dari makanan yang masuk, sehingga gizi berpengaruh pada kondisi daya tahan tubuh balita diatas umur tersebut.

\section{Jenis Kelamin}

Hasil penelitian menunjukan balita dengan jenis kelamin laki-laki lebih banyak daripada jenis kelamin perempuan, jika dibandingkan dengan penyakit pneumonia beberapa penelitian menunjukkan adanya hubungan antara jenis kelamin laki-laki dan perempuan, walaupun dalam penelitian ini hubungan antara jenis kelamin dan penyakit pneumonia tidak diteliti karena proporsi jumlah yang hampir sama antara keduanya. Menurut Puspitasari dan Fariani (2013), ada banyak faktor yang berpengaruh pada jenis kelamin yang menyebabkan pneumonia seperti perbedaan hormon, status imunisasi, pemberian ASI eksklusif, paparan polusi, perbedaan pola asuh dan daya tahan atau kerentanan bayi dengan jenis kelamin lakilaki yang lebih tinggi daripada bayi dengan jenis kelamin perempuan. 


\section{Riwayat Pemberian ASI Eksklusif}

Pemberian ASI eksklusif adalah pemberian ASI tanpa adanya makanan atau minuman lain termasuk air putih kecuali obat, vitamin dan mineral serta ASI yang diperas. ASI diketahui memberikan proteksi yang besar bagi balita karena sangat berperan untuk meningkatkan imunitas dari bayi. Jumlah balita yang mendapat asupan ASI yang cukup lebih banyak daripada yang tidak. Hasil penelitian ini menunjukkan bahwa variabel status riwayat pemberian ASI mempunyai nilai $\mathrm{OR}=7,407$ yang dapat disimpulkan bahwa kelompok balita yang riwayat pemberian ASI tidak eksklusif berisiko 7,407 kali lebih besar terkena pneumonia balita daripada kelompok balita yang pemberian ASInya eksklusif.

Temuan ini sejalan dengan Fanada (2012) yang menunjukkan resiko 5,2 kali lebih besar terkena pneumonia bagi bayi yang pemberian ASInya tidak eksklusif. Menurutnya pemberian ASI secara eksklusif penting sampai umur 6 bulan dan MPASI setelah umur tersebut, hal ini dipengaruhi oleh masih banyaknya ibu yang tidak mengetahui tentang ASI eksklusif dan berhenti menyusui sebelum mencapai umur 6 bulan. Zat gizi yang diperlukan oleh balita sudah tercukupi dengan ASI dan sesuai dengan acuan standar yang diberlakukan oleh WHO, begitupula pemerintah Indonesia. Menyusui secara eksklusif menurunkan risiko balita untuk terkena pneumonia dan juga penyakit lain karena adanya imunitas yang befungsi meningkatkan imunitas balita.

Hasil penelitian ini juga didukung oleh penelitian Puspitasari dan Fariani (2015) yang menyatakan balita yang tidak diberi ASI eksklusif berisiko 7 kali lebih besar terkena pneumonia balita dibandingkan dengan yang diberi ASI secara eksklusif. Menurutnya ASI mengandung berbagai macam zat yang meningkatkan kekebalan tubuh dan melindungi dari berbagai macam penyakit, beberapa diantaranya adalah immunoglobulin $A$ yang berasal dari hasil sekresi kelenjar susu yang berfungsi untuk mengikat mikroorganisme seperti virus ataupun bakteri, adanya laktoferin, lisozim yang berfungsi menghancurkan bakteri, leukosit, makrofag untuk sintesis immunoglobulin dan faktor antistreptokokus yang mencegah dari penyakit yang berhubungan dengan sistem pernapasan seperti influenza dan pneumonia. ASI juga memberikan nutrisi yang berfungsi sebagai makanan sekaligus sebagai faktor yang meningkatkan pertumbuhan balita karena kombinasi dari ASI sangat cocok untuk bayi daripada susu olahan atau formula. Hal tersebut dikaitkan dengan kandungan protein dalam ASI yang sangat tinggi, dimana kandungan protein dari ASI dan susu formula terdapat perbedaan jumlah protein yang dapat diserap oleh balita. Kandungan protein dalam susu formula biasanya didominasi oleh casein, sedangkan dalam ASI didominasi oleh whey, dimana protein jenis whey lebih mudah diserap oleh usus bayi daripada jenis casein. Hal tersebut yang membedakan antara kandungan dari susu formula dan ASI, dan jelas menyebutkan jika ASI secara alami yang didapat dari ibu balita lebih baik daripada susu formula walaupun kandungan yang ada didalamnya hampir mirip dengan ASI yang sebenarnya.

Penelitian sejalan lain yang diungkap oleh Hartati, dkk. (2012) dengan OR 4,47 kali lebih berisiko bagi balita yang tidak mendapatkan ASI eksklusif. Hartati mengungkapkan jika salah satu faktor yang menyebabkan balita lebih mudah terserang pneumonia adalah tidak diberikannya ASI secara eksklusif pada balita, begitupula dalam penelitiannya jumlah balita yang tidak menerima ASI secara eksklusif dan mengalami pneumonia mencapai $50 \%$ dari keseluruhan sampel penelitiannya, sedangkan balita yang mendapatkan ASI eksklusif dan tidak terkena pneumonia mencapai $80 \%$ dari total sampel. Hal tersebut menggambarkan jika ASI eksklusif sangat berpengaruh terhadap kejadian pneumonia. Hasil kuat 
hubungan penelitian ini secara statistik sebesar 0,455 yang berarti sifat hubungan yang cukup lemah. Hal ini juga diutarakan oleh Domili, dkk. (2013) yang menyatakan bahwa tidak ada hubungan antara pemberian ASI eksklusif dengan kejadian pneumonia.

Perlu diketahui pula, jika banyak faktor yang dapat mempengaruhi perilaku ibu dalam memberikan ASI secara eksklusif pada balitanya. Menurut Yani dkk. (2009), faktor yang mempengaruhi pemberian ASI eksklusif dibagi menjadi 3 kategori besar yaitu faktor predisposisi, faktor pendukung dan faktor pendorong. Faktor predisposisi yang diteliti dalam penelitiannya adalah faktor pengetahuan dan faktor sikap. Faktor pengetahuan yang dimaksud disini adalah ibu yang memiliki pengetahuan tentang manfaat, keunggulan, dan cara pemberian ASI yang benar akan mendorong ibu balita untuk memberikan ASI pada balitanya, karena pengetahuan adalah bekal awal seseorang untuk bertindak dimana pengetahuan yang baik akan mendasari tindakan yang baik, begitu pula sebaliknya jika pengetahuan yang dipunyai buruk maka tindakan yang akan dilakukan akan buruk pula.

Faktor predisposisi yang lainnya adalah sikap. Sikap yaitu respon dari seseorang untuk menanggapi suatu rangsangan dari obyek tertentu. Sikap ini menentukan seseorang untuk berperilaku dan bertindak sesuai dengan pengetahuan dan emosi orang tersebut. Sikap ini menentukan respon ibu balita untuk memberikan ASI kepada balitanya dimana sikap positif atau setuju akan pemberian ASI yang didasari oleh pengetahuan yang baik akan berperan pada tindakan dan perilaku ibu balita untuk menyusui secara eksklusif pada balitanya (Yani dkk., 2009).

Salah satu faktor pendukung terjadinya adalah pengaruh dari ketersediaan makanan ibu terhadap perilaku menyusui balitanya. Ibu balita yang konsumsi makannya tidak sesuai dengan kebutuhan atau kekurangan pasokan makanan akan berdampak pada tindakan ibu untuk memberikan ASI pada balitanya misalnya dengan alasan volume ASI yang sedikit. Kekurangan makanan salah satunya akan berdampak pada kekurangan gizi ibu balita yang akan diturunkan pada balitanya, keadaan ini dapat mengakibatkan produksi hormon prolaktin yang berfungsi meningkatkan sekresi air susu berkurang sehingga jumlah ASI yang dikeluarkan menjadi sedikit. Kebutuhan gizi ibu balita dalam enam bulan pertama juga perlu diperhatikan, penambahan energi sebesar $700 \mathrm{kkal}$ dan protein sebanyak 16 gram diperlukan untuk enam bulan pertama untuk meningkatkan produksi ASI kurang lebih sebanyak $750 \mathrm{ml}$. Jumlah tersebut penting untuk demi kelancaran pemberian ASI secara eksklusif balita pada awal masa pertumbuhannya (Yani dkk., 2009).

Manfaat dan kandungan dari ASI sangat beragam dimulai dari kolostrum yang mengandung protein sebesar $16 \%$, imunoglobulin A (Ig A), laktoferin dan selsel darah putih yang kesemuanya penting untuk mencegah infeksi penyakit, lalu kandungan vitamin A dan mineral-mineral lainnya serta mengandung sedikit lemak dan laktosa. ASI sangat mudah diserap oleh bayi contohnya zat besi dapat diserap sebesar $75 \%$ dari kandungan yang ada di dalamnya daripada susu formula yang hanya diserap sebesar 5-10\% (Mahayu, 2014).

ASI sangat penting bagi bayi selama 2 tahun pertama kehidupannya. Walaupun susu olahan sapi ataupun formula lain dapat memenuhinya akan tetapi masih ada perbedaan antara ASI alamiah dan susu formula. Pengganti ASI hanya diberikan jika memang ada faktor tertentu sehingga seorang Ibu tidak dapat memberikan ASInya atau kualitas ASI yang kurang baik. ASI diberikan 30 menit segera setelah ibu melahirkan sampai umur 6 bulan dan seterusnya sampai 2 tahun. selanjutnya pengenalan MPASI pada umur 6 bulan. Beberapa faktor yang menyebabkan ASI lebih baik dibandingkan susu formula yaitu ASI mengandung zat gizi yang lebih sesuai dengan apa yang dibutuhkan oleh balita, ASI 
didapatkan langsung dari ibu ke bayinya, ASI meringngankan fungsi sistem pencernaan dan ginjal balita, ASI masih sangat alami dan bebas dari cemaran kuman, ASI mengandung antibodi dan melindungi balita dari minggu-minggu pertama kelahirannya, dan secara mental ASI meningkatkan rasa keibuan bagi orang tua dan rasa aman bagi bayinya (Mahayu, 2014).

Faktor lain yang menyebabkan ASI lebih baik dikonsumsi oleh bayi karena dapat melindungi dari penyakit adalah yaitu kebersihan ASI yang lebih baik, immunoglobulin yang lebih banyak berfungsi sebagai pelindung untuk melawan bakteri, laktoferin yang dapat mengikat zat besi untuk menahan bakteri patogen berkembang biak, lisozim sebagai enzim yang protektif bagi bayi dengan menghancurkan bakteri dan menahan serangan virus, sel-sel darah putih yang banyak dan faktor bifidus untuk pertumbuhan bakteri non patogen (Mahayu, 2014). Faktor-faktor diatas dapat mencukupi status gizi balita dan membantu untuk meningkatkan imunitas terhadap serangan penyakit misalnya pneumonia.

\section{Luas Ventilasi Ruangan}

Balita dengan ruangan kamar yang luas ventilasinya standar lebih banyak pada sampel penelitian ini, akan tetapi untuk populasi kasus jumlah terbanyak adalah balita yang luas ventilasi ruangan kamarnya kurang dari standar. Hasil penelitian ini menunjukkan bahwa variabel luas ventilasi ruangan mempunyai nilai $\mathrm{OR}=13,5$ yang dapat disimpulkan bahwa kelompok balita yang luas ventilasi ruangannya $<20 \%$ luas lantai ruangan berisiko 13,5 kali lebih besar terkena pneumonia balita daripada kelompok balita yang luas ventilasi ruangannya standar ( $\geq 20 \%$ ). Begitupula dengan penelitian oleh Soelandono (2008) yang menyatakan kondisi ventilasi ruangan kamar balita yang tidak memenuhi syarat mempunyai risiko sebesar 2,67 kali lebih besar untuk terjadi pneumonia daripada kondisi ventilasi kamar tidur yang memenuhi syarat. Dijelaskan dalam penelitian Soelandono jika ventilasi yang lancar diperlukan untuk menghindarkan pengaruh berkurangnya kadar oksigen dalam ruangan, bertambahnya karbondioksida dari hasil pernapasan manusia, bau pengap yang dihasilkan oleh kulit, keringat, pakaian dan mulut akibat aktivitas manusia, suhu yang meningkat menjadi lebih panas dan kelembaban udara yang bertambah akibat penguapan air dari kulit dan napas manusia. Pengaruh dari faktor tersebut akan berimplikasi pada daya tahan tubuh balita serta berkembang biaknya mikroorganisme yang memudahkan penyebaran penyakit melalui udara dalam ruangan dan salah satunya adalah pneumonia.

Penelitian oleh Mahalastri (2014) mendukung pernyataan $\mathrm{Hg}$ bentilasi ruangan, yaitu jika rumah responden dengan luas ventilasi yang kurang dari syarat minimal mempunyai risiko sebesar 4,03 kali lebih besar untuk terjadinya pneumonia balita daripada rumah responden yang termasuk kategori standar atau memenuhi syarat minimal. Dijelaskan jika rumah sehat adalah rumah yang memenuhi syarat kesehatan seperti ventilasi rumah yang baik dan kepadatan hunian yang sesuai. Ditambahkan olehnya bahwa ventilasi ruangan berpengaruh terhadap pertukaran udara yang berujung pada gangguan kesehatan akibat mikroorganisme, selain itu perannya untuk menjaga kadar oksigen, jumlah karbondioksida dan kelembapan udara serta mengatur gas lain dalam ruangan.

Hasil kuat hubungan dalam penelitian ini bernilai 0,524 yang berarti hubungan yang cukup kuat antara luas ventilasi dengan kejadian pneumonia. Pada tabel 5.19 menunjukkan luas ventilasi yang kurang lebih banyak menyebabkan pneumonia dibanding dengan luas ventilasi yang standar. Fakta di lapangan juga membuktikan kalau rata-rata responden dengan luas ventilasi yang kurang sehingga minim cahaya masuk, lubang ventilasi jarang dibuka dan banyak yang sudah rusak. 
Menurut Kemenkes R.I. (2011) kualitas udara yang buruk dalam ruang rumah dapat menimbulkan berbagai macam masalah kesehatan. Laju ventilasi yang buruk dapat menyebabkan pertukaran udara yang tidak memenuhi syarat dan memudahkan pertumbuhan mikroorganisme. Pertumbuhan bakteri, jamur, kutu, Legionella, Clostridium, streptococcus aureus. alga maupun serangga dapat dengan mudah menetap pada ruangan dengan kondisi laju angin yang rendah.

Retna dan Umi (2015), menyatakan jika aliran udara atau penghawaan dalam ruangan bukan hanya aliran udara satu arah saja akan tetapi aliran udara harus dapat menyediakan udara masuk yang segar dan mengeluarkan udara yang kotor dimana mekanisme masuk dan keluarnya udara harus seimbang dan teratur. Anwar dan Ika (2014), menambahkan jika fungsi aliran udara tidak lancar dalam ruangan akan memudahkan zat pencemar dalam ruangan bertahan lebih lama dalam ruangan dan mengakibatkan paparan zat pencemar dalam ruangan menjadi lebih tinggi bagi individu yang berada di dalam ruangan, khususnya balita yang masih rentan terhadap paparan buruk untuk saluran pernapasannya. Perubahan suhu yang terlalu tinggi atau rendah salah satunya diakibatkan oleh ventilasi yang tidak memenuhi syarat. Perubahan suhu ekstrim dapat mempengaruhi kondisi tubuh balita. Daya tahan tubuh balita dapat menurun akibat suhu yang terlalu panas ataupun suhu yang terlalu dingin karena balita masih rentan untuk menyesuaikan suhu disekitarnya apalagi balita pada mingguminggu awal kelahirannya. Kelembaban yang terlalu tinggi dapat mempengaruhi pertumbuhan mikroorganisme, sedangkan jika terlalu rendah maka dapat menyebabkan keringnya selaput luar mata ataupun kulit (Prasasti, dkk. 2005).

Kelembapan tinggi menyebabkan kandungan air dalam udara menjadi tinggi, hal tersebut menyebabkan bakteri dengan mudah mengambil air dari udara sehingga perkembangbiakan lebih mudah karena rata-rata jamur dan bakteri memerlukan kelembaban tinggi sekitar $80-85 \%$. Cahaya matahari yang masuk berpengaruh terhadap suhu ruangan dan juga proses perkembangan bakteri, cahaya matahari mengandung ultraviolet yang mengakibatkan sebagian besar bakteri mati karena pertumbuhannya tidak bergantung pada cahaya matahari atau chemotrophe selain itu sebagian virus influenza juga tidak akan aktif jika terpapar sinar matahari (Budiyanto, 2010).

Faktor risiko pneumonia yang berupa agent penyakit biasa menular melewati udara dimana pengaruhnya adalah terhadap kejadian pneumonia pada balita. Upaya untuk menghindari penyakit pneumonia yaitu menempatkan kasa atau perangkap debu, menjaga kebersihan ruangan, dan menambah ventilasi udara pada ruangan agar memenuhi syarat adanya ventilasi sekurang-kurangnya $20 \%$ dari luas lantai ruangan.

\section{SIMPULAN}

Hasil penelitian menunjukkan adalah balita dengan riwayat ASI tidak eksklusif berisiko 7,4 kali lebih besar untuk terkena pneumonia dibandingkan dengan balita yang riwayat pemberian ASInya eksklusif. Balita yang mendiami ruangan dengan luas ventilasi ruang kurang dari 20\% luas lantai (tidak standar) berisiko terkena pneumonia sebesar 13,5 kali daripada balita yang luas ruangannya $\geq 20 \%$ luas lantai ruang kamar atau standar.

Ibu balita hendaknya menjalankan pola hidup sehat bagi anaknya dan dirinya sendiri dengan tetap menjaga kebersihan ruangan dan kebersihan balita maupun dirinya, menghindarkan paparan asap rokok pada balita, menghindarkan balita polusi udara dan lingkungan yang kotor, serta aktif ke posyandu untuk memeriksakan kondisi balita secara teratur agar tetap sehat. Ibu balita perlu untuk tetap memberikan ASI secara eksklusif pada bayinya sampai usia minimal 6 bulan lalu dilanjutkan sampai usia 
2 tahun. Ibu balita diharapkan memberikan ASI pertama saat awal-awal kelahiran bayi karena banyak mengandung kolostrum yang berisi antibodi, selain itu setelah umur 6 bulan diperlukan pengenalan MPASI dimana makanan pendamping ASI berfungsi untuk mengenalkan jenis-jenis makanan dan membantu melengkapi nutrisi yang semakin tinggi dibutuhkan oleh balita yang semakin tumbuh besar. Faktor luas ventilasi di dalam ruangan kamar balita perlu diperhatikan oleh kedua orang tua balita, dengan memperluas ventilasi yang ada dengan cara menambah lubang ventilasi pada dinding misalnya dengan tambahan jendela atau memasang kipas blower pada dinding sehingga aliran udara dapat keluar masuk ruangan, selain itu menambahkan genteng kaca pada atap ruang untuk meningkatkan cahaya yang masuk kedalam ruangan. Pemasangan kipas angin dalam ruangan dan sering membuka jendela, pintu dan lubang angin lainnya agar meningkatkan sirkulasi udara dalam ruangan kamar balita.

Bagi stakeholder, perlunya untuk sosialisasi dan pelatihan bagi para kader atau bidan yang bertugas untuk mempromosikan ASI eksklusif karena masih banyak ibu balita yang tidak mengerti tentang ASI eksklusif. Penyampaian ASI eksklusif diharapkan mengurangi angka kematian balita akibat pneumonia. Promosi ASI eksklusif dengan sasaran orang tua balita maupun umum dapat dilakukan pada saat posyandu, pekan kesehatan yang diadakan di berbagai tingkat, paling kecil adalah tingkat rukun warga dan rukun tetangga dengan adanya perkumpulan atau organisasi kemasyarakatan. Program pemerintah lainnya adalah sosialisasi aturan dan pedoman untuk membangun rumah yang sehat, dimana salah satu indikator rumah sehat adalah ventilasi yang baik. Peningkatan program pembangunan rumah sehat bagi masyarakat yang umumnya berada di pedesaan dan berada dibawah garis kemiskinan. Rumah tersebut harus dirombak sesuai dengan standar dan peraturan yang ada.
Bagi penelitian selanjutnya yang berhubungan dengan topik ini, disarankan untuk menambahkan faktor risiko yang lebih luas seperti berat bayi lahir rendah, tingkat pelayanan kesehatan, pengetahuan dan pendidikan ibu, serta pola asuh anak.

\section{DAFTAR PUSTAKA}

Adriani, M., Bambang, W. 2012. Pengantar Gizi Masyarakat. Jakarta. Kencana Prenada Media Group.

Anwar, A., Ika, D. 2014. Pneumonia pada Anak Balita di indonesia. Jurnal Kesehatan Masyarakat Nasional, [e-journal] 8(1): pp. 359-365.http:// jurnalkesmas.ui.ac.id/ index.php/kesmas/article/view/405/402. [Sitasi 6 Juni 2016].

Budiyanto, A.K. 2010. Pertumbuhan Mikroorganisme.https://zaifbio. wordpress. com/2010/11/08/ pertumbuhan-mikroorganis me/. [Sitasi 6 Juni 2016].

Domili, M.F. H., Wema, N., Vivien, N.A., Kasim, 2013. Faktor-Faktor yang Berhubungan dengan Kejadian Pneumonia pada Balita di Wilayah Kerja Puskesmas Global Mongolato. Artikel Jurnal. kim. ung.ac.id/index.php/KIMFIKK/article/ download/2781/2757. [Sitasi 6 Juni 2016].

Fanada, M. 2012. Faktor-Faktor yang Berhubungan dengan Kejadian Penyakit Pneumonia pada Balita di Wilayah Kerja Puskesmas Kenten Palembang Tahun 2012. Sumatera Selatan. Jurnal Badan Diklat Provinsi Sumatera Selatan. http:// www.banyuasinkab.go.id/tampung/ dokumen/dokumen-15-33.pdf. [Sitasi 6 Juni 2016].

Fikri, B.A. 2016. Analisis Faktor Risiko Daya Tahan Tubuh Balita dan Status Lingkungan Rumah terhadap Kejadian Pneumonia Balita. Skripsi. Fakultas Kesehatan Masyarakat Universitas Airlangga Surabaya.

Hartati, S., Nani, N., Dewi, G. 2012. Faktor Risiko Terjadinya Pneumonia pada Anak Balita. Jurnal Keperawatan Indonesia. 
[e-journal]. 15(1): pp. 13-20. http://jki. ui.ac.id/index.php/jki/article/view/42/42. [Sitasi 6 Juni 2016].

Kementerian Kesehatan R.I., 2011. Peraturan Menteri Kesehatan R.I. Nomor 1077/ Menkes/Per/V/2011 tentang Pedoman Penyehatan Udara dalam Ruang Rumah.

Kementerian Kesehatan R.I., 2013. Riset Kesehatan Dasar 2013. Jakarta. Badan Penelitian dan Pengembangan Kesehatan Republik Indonesia.

Kementerian Kesehatan R.I. 2013. Profil Kesehatan Indonesia 2012. Jakarta. Kementerian Kesehatan Republik Indonesia.

Kementerian Kesehatan R.I. 2014. Profil Kesehatan Indonesia 2013. Jakarta. Kementerian Kesehatan Republik Indonesia.

Last, M. J. 2001. A Dictionary of Epidemiology $4^{\text {th }}$ Edition. New York. Oxford University Press.

Mahalastri, Ni Nyoman Dayu. 2014. Hubungan antara Pencemaran Udara dalam Ruang dengan Kejadian Pneumonia Balita. Jurnal Berkala Epidemiologi, [e-journal] 2(3): pp. 392-403. http:// ejournal.unair.ac.id/ index.php/JBE/ article/view/1305/1064. [Sitasi 6 Juni 2016].

Mahayu, P. 2014. Imunisasi dan Nutrisi. Yogyakarta. Penerbit Buku Biru.

Prasasti, C.I., J. Mukono., Sudarmaji. 2005. Pengaruh Kualitas Udara Dalam Ruangan Ber-AC Terhadap Gangguan Kesehatan. Jurnal Kesehatan Lingkungan. 1(2) pp. 160-169.

Puspitasari, D.E., Fariani, S. 2015. Faktor Risiko Pneumonia Pada Balita Berdasarkan Status Imunisasi Campak dan Status ASI Eksklusif. Jurnal Berkala Epidemiologi, [e-journal] 3(1): pp. 69-81. http://e-journal.unair.ac.id/index.php/ JBE/article/view/1315/1074. [Sitasi 6 Juni 2016].
Retna, R., Umi, N.F. 2015. Gambaran Karakteristik Kejadian Pneumonia pada Balita di Puskesmas Wanadadi 1 Kabupaten Banjarnegara Tahun 2014. Medsains, [e-journal] 1(1): pp. 18-22. http://www.polibara.ac.id/wp-content/ uploads/2015/04/RusfitaRetna.pdf. [Sitasi 6 Juni 2016].

Sarbini, D., Listyani, H. 2008. Hubungan antara Tingkat Pendapatan Keluarga dan Pendidikan Ibu dengan Pemberian ASI Eksklusif di Kecamatan Jebres Kotamadya Surakarta. Jurnal Kesehatan, [e-journal] 1(2): pp 115-122. https://publikasiilmiah. ums.ac.id/bitstream/handle/11617/1462/ jurnal $\% 20 \mathrm{kes} \% 20 \mathrm{vol} \% 201 \% 20 \mathrm{no} \% 20$ $2 \% 20 \mathrm{~d} \% 20115-122$.pdf? sequence $=3 \&$ is Allowed=y. [Sitasi 5 Juni 2016].

Sartono, A., Hanik, U. 2012. Hubungan Pengetahuan Ibu, Pendidikan Ibu dan Dukungan Suami dengan Praktek Pemberian Asi Eksklusif di Kelurahan Muktiharjo Kidul Kecamatan Telogosari Kota Semarang. Semarang. Jurnal Gizi Universitas Muhammadiyah Semarang, [e-journal] 1(1): pp. 1-9. http:// jurnal. unimus.ac.id/index.php/jgizi/article/ view/565/615. [Sitasi 5 Juni 2016].

Soelandono, D.K. 2008. Pengaruh Faktor Ibu dan Faktor Lingkungan dalam Rumah terhadap Kejadian Pneumonia Balita. Skripsi. Fakultas Kesehatan Masyarakat Universitas Airlangga Surabaya.

Sugihartono, Pasiyan, R., Nurjazuli. 2012. Analisis Faktor Risiko Kejadian Pneumonia Pada Balita di Wilayah Kerja Puskesmas Sidorejo Kota Pagar Alam. Jurnal Kesehatan Lingkungan Indonesia, 11(1): pp.82-86.

Wahid, A., Imam, S. 2013. Keperawatan Medikal Bedah, Asuhan Keperawatan pada Gangguan Sistem Respirasi. Jakarta Timur. Trans Info Media, Jakarta. 
World Health Organization (WHO). 2013. End Preventable Deaths: Global Action Plan for Prevention and Control of Pneumonia and Diarrhoea. Geneva. UNICEF. www.who.int. [Sitasi 5 Juni 2016].
Yani, I.E., Defriani, D., Novelasari. 2009. Faktor-Faktor yang Mempengaruhi Perilaku Ibu Laktasi dalam Memberikan ASI di 6 Kabupaten/Kota di Provinsi Sumatera Barat. PGM. 32(2) pp. 101-111. 